\title{
ETIIKKAA ARKEEN JA TIETEESEEN
}

JUKKA HANKAMÄKI (2003) Dialoginen filosofia. Teoria, metodi, politiikka. Yliopistopaino, 371s.

Uudessa teoksessaan Dialoginen filosofia. Teoria, metodi ja politiikka Jukka Hankamäki kritisoi niin tieteessä, politiikassa kuin ihmisten arkipäivässäkin vallitsevia ajattelutapoja ja uskomuksia. Uskollisena fenomenologiselle traditiolle hän tekee sen menemällä asiaan itseensä, siis radikaalisti. Jo väitöskirjassaan Rakkauden välittäjä hän pyrki löytämään etiikan teorian rakennusaineet, silloin Simone Weilin filosofiasta. Hankamäki pakottautui Weilin tapaan ihmisen elämän representaatioista maan pinnalle etsimään ihmistä ja todellista teoriaa ihmisestä konkreettisissa elämän tilanteissa. Etsintä jatkuu. Nyt hän ottaa avukseen dialogisen filosofian edustajat Martin Buberin ja Emmanuel Levinasin. Heidän tuellaan hän pyrkii löytämään sekä tieteen että arjen etiikan.

Arkielämämme on ahdettu ja olemme itse ahtamassa sitätäyteen erilaisia "teorioita": mielikuvia, tekniikoita, metodeja, kyseenalaistamattomia pakkoja, ennakkoluuloja ja niihin kytkeytyviä pelkoja. Me emme useinkaan edes hämmästele niitä, ja tuskin koskaan aidosti kohtaamme ne. Hankamäki kuitenkin uskaltautuu näin tekemään. Hänen valitsemansa oppaat, Buber ja Levinas, ovat oivallisena apuna tiellä, jolla kulkeval- le "osoitetaan jotakin todellisuudesta, jota ei enää nähdä, tai nähdään liian vähän.” Erityisesti Hankamäkeä kiinnostaa, mitä annettavaa edellä mainituilla filosofeilla on toiseuden, erilaisuuden ja ulkopuolisuuden kysymysten käsittelyyn ja miten dialogiseen ihmistieteeseen voitaisiin edetä fenomenologisen filosofian keinoin.

Teos jakautuu - kuten alaotsikkokin antaa ymmärtää - kolmeen osaan: teoriaan, metodiin ja politiikkaan. Kirjan teoreettinen osa on Buberin ja Levinasin filosofiaa tuntevallekin erinomaisen antoisa. Kummankin filosofia on kuvattu asiantuntevan syvällisesti, mutta samalla konstailematta ja harvinaisen selkeästi. 


\section{DIALOGISUUS JA} EETTISYYS ARJESSA

Todellisessa dialogissa toinen kohdataan omana itsenään pyrkimättä sulauttamaan ja häivyttämään häntä mihinkään ennalta määriteltyyn perustaan. Todelliseen dialogiin pääsemisen esteenä ovat erilaiset yhteiskunnalliset reunaehdot ja valtarakenteet. Mutta ne ovat ihmisen rakentamia, joten niiden olemassaolon tunnistaminen ei vielä oikeuta luopumaan pyrkimisestä dialogiin. Ne saattavat olla piileviä, kuten Foucault meille muistuttaa, mutta ne ovat ihmisen mittaisia. Yhteiskunnallisten rakenteiden olemassaolon myöntämisen ei siis pidä antaa johtaa siihen, että levitämme kätemme ja luovumme pyrkimyksestä yhdessä pohtivaan ja yhdessä pohdittuun toimintaan. Realistisempaa on pyrkiä kohtaamaan marginaaliehdot arkipäivän elämäntilanteissa sellaisina, kuin ne näyttäytyvät ihmisen elämismaailmassa, hänen toiminnassaan ja kokemuksissaan, hänen ajatuksissaan omasta itsestään maailmassa olevana, hänen käsityksistään toisista ihmisistä, uskomuksissaan, ennakkoluuloissaan, peloissaan jne.

On olennaisen tärkeää, että asioita pyritään tarkastelemaan, kuten Levinas kehottaa, ilman illuusioita ja retoriikkaa. On siis tarpeen Hankamäen tapaan fenomenologisesti pohtia, miten asiat voidaan ajatella uudella tavalla ja miten niitä voidaan yhdessä pohtien ja toimien muuttaa. Varsinkin meidän pedagogien on syytä - vaikka marginaaliehdot meitä ahdistaisivat ja kuristaisivat - silloin tällöin muistuttaa itseämme Levinasin ajatuksesta, jonka mukaan ihmisen suhteen toiseen on perustutta- va pyyteettömyyteen, yritykseen olla vastikkeettomasti eettinen, hyvä tai vähintään siedettävä, jotta maailmassa voisi olla edes jotain hyvää. Hankamäki osoittaa teoksellaan, että tällainen ajatteleminen ja konkreettinen toiseen suhteessa oleminen, myös toiminnan tasolla, on luultua useammissa elämäntilanteissamme mahdollista.

Vaikka elämmekin jälkimodernissa yhteiskunnassa, ihmisillä on arkielämässään taipumus yhä edelleen vedota jo ajateltuun, "vahvoihin auktoriteetteihin" ja sellaisiin ratkaisuihin, joista selviää pelkällä kalkyloivalla, laskevalla ajattelulla ja sen ohjastamalla toiminnalla: siis toimimalla rutiininomaisesti, noudattamalla valmiiksi annettuja toimintaohjeita, heittäytymällä kyselemättä yhteiskunnan ja yhteiselämän asettamien marginaaliehtojen uhriksi, toisin sanoen toimimalla niin kuin muutkin toimivat.

Pelkästään tavoiterationaaliselle, laskevalle ajattelulle rakentuvien ajatusten ja toimintamuotojen varassa varsinainen eettinen elämä ei kuitenkaan ole mahdollista. Niiden mukaan toimittaessa ratkaisut perustuvat, ei yksilön itsensä pohtimiin ja hyväksymiin eettisiin perusteisiin, vaan ulkoapäin omaksuttujen, tavoiterationalististen normien seuraamiseen. Tällöin yksilön toimintaa ei voida pitää varsinaisesti eettisenä - hän muistuttaa enemmän varashälytintä, kuten Heikki Mäki-Kulmala Aamulehdessä osuvasti totesi. Koska vain yksilö voi olla eettinen, elävä etiikka on aina yksilön etiikkaa, ei yhteisön. Yhteisöt eivät ajattele eivätkä koe. Ne käyttäytyvät. Tämä ei luonnollisestikaan tarkoita sitä, että Levinasin ja Buberin toi- seuden merkitystä korostavassa filosofiassa yksilölle luotaisiin riippumattomuuden illuusio. Absoluuttinen vapaus on mahdottomuus ja toinen ihminen rajoittaa aina yksilön vapautta.

\section{DIALOGINEN METODI TUTKIMUSMETODINA}

Sitoutumatonta kasvatustiedettä ei ole olemassa. Niin aikuiskasvattajan kuin kasvatustieteilijänkin on myös tiedettä tehdessään vakavasti ja vastuullisesti tarkasteltava itseään, omia toimiaan ja niiden perusteita. Tässä vaikeassa tehtävässä Hankamäen teos on hyvänä apuna. Hän keskittyy teoksensa toisessa osassa siihen, miten dialogiseen ihmistieteeseen voitaisiin edetä fenomenologisen filosofian keinoin. Vaikka dialoginen metodi on - ainakin sanana - monelle aikuiskasvatuksen ja kasvatustieteen edustajalle tuttu, perinteisen ja hermeneuttis-fenomenologisen paradigman ero ei vielä näytä tulleen selväksi. Dialogista metodia käyttävä hermeneuttis-fenomenologisen paradigman edustaja joutuu yhä edelleen olemaan altavastaajana tai mukautumaan vanhan paradigman ehtoihin ja pelisääntöihin saadakseen itsensä edes jollakin tavalla kuulluksi, ymmärretyksi ja hyväksytyksi. Hankamäen teos on hyvä opas jokaiselle, joka haluaa pintaa perusteellisemmin tutustua dialogiseen metodiin ja sen perusteisiin.

Hankamäki osoittaa, mitä merkitystä jo pelkällä kohtaamiseen liittyvällä asenteella tai asenteenmuutoksella voi olla tieteelle. Sekä Buberilla että Levinasilla on myös tieteen tekemisessä lähtökohtana se, että toinen ihminen on toiselle ar- 
voitus, joka ei antaudu kokonaan määrittelyille. Toista on mahdotonta muotoilla läpinäkyväksi tiedoksi. Toinen on aina enemmän, kuin minä voin käsittää. Ihmisen tutkiminenkin on näin ollen perimmältään ainutlaatuisuuden, erilaisuuden ja vierauden kohtaamista. Se on selittämättömän selittämistä.

\section{POLITIIKKA}

Jotta tieteellinen tiedonmuodostus olisi loppuun saakka eettinen prosessi, sen tulisi tuottaa tietoa ja ymmärrystä, jolla on rakentava yhteiskunnallinen merkitys. Tämän kantansa Hankamäki tuo selkeästi esiin sekä teoksensa sisällöissä että sen rakenteessa. Hän katsoo, että ihmistieteellisen tutkimuksen lähtökohtana voidaan pitää (a) dialogista kohtaamista, toisena vaiheena (b) kriittistä fenomenologista tiedonmuodostusta ja kolmantena vaiheena (c) tiedon ja ymmärryksen palautumista ihmisen elämismaailmaan. Hankamäen teoksessaan raportoima tutkimus on oiva esimerkki tällaisesta hermeneuttisesta tutkimusprosessista.

Teoksen kolmas osa, kohdallisen ihmistieteellisen tutkimuksen kolmas vaihe, on siis eettisesti ja uskottavuussyistä välttämätön. Se on kuitenkin tutkimuksen ehkä haastavin ja vaikein, koska siinä Hankamäki tarkastelee laaja-alaisesti erilaisia yhteiskunnallisia eettisiä ongelmia pyrkien keskustelevan filosofian keinoin niihin vastaamaan. Hankamäki käsittelee monia - ehkä jonkun mielestä liian monia - niin sanotulle harmaalle vyöhykkeellekin sijoittuvia ongelmia. Seksuaalivähemmistöjen asema on lähellä hänen sydäntään. Eniten tilaa saa- vat kuitenkin yleisemmin syrjäytymisen, eriarvoisuuden ja etnisyyden kysymykset. Yhdenkään ongelman käsittely ei kuitenkaan sinänsä ole turha. Käsitellyt ongelmat ovat konkreettisia esimerkkejä meidän aikamme kovuudesta - siitä, että emme enää koe samassa määrin kuin aikaisemmin olevamme eettisesti vastuussa syrjäytyneistä ja vähempiosaisista. Jokainen esimerkeistä muistuttaa - usein idealismista syytetyn - dialogisen filosofian tarpeellisuudesta elämämme eri alueilla. Hankamäen edustaman lähestymistavan pätevä esilletuominen on erityisen tarpeellista näinä päivinä, jolloin ihmisenä olemisen ongelmat pyritään ohentamaan vain teknologis-taloudellisiksi ja teknis-rationaalisen, kalkyloivan ajattelun keinoin ratkaistaviksi. Kasvatustieteissä tämä trendi näyttäytyy esimerkiksi siinä, että keskitytään yksipuolisen tavoiterationaalisesti erilaisten asioiden oppimisen manipulointikeinojen kehittämiseen. Itse asia, kasvatus, kiinnostaa enää harvoja kasvatustieteilijöitä.

Hankamäen yhteiskunta- ja kulttuurikritiikkiä ei voi syyttää ainakaan kesyydestä eikä rohkeuden puutteesta. On hyvin todennäköistä, että hänen persoonallinen ja kriittisesti kantaa ottava teoksensa herättää voimakkaita tunneryöppyjä muissakin lukijoissa kuin Tapani Kilpeläisessä, joka arvosteli Hankamäen teoksen Yliopisto-lehdessä ( Yliopisto 12-13, 2003). Kilpeläinen odotti, että teoksessa - lähinnä sen politiikkaosassa olisi vielä enemmän pohdintaa ja pistävämpiä argumentteja. Hänen omasta vihjailevasta ja ylimielisestä kritiikistään ne molemmat ikävä kyllä lähes täy- sin puuttuivat. Vaikka Kilpeläinen kiittääkin Hankamäen teoksen vahvuutta ja ansiokkuutta fenomenologisen etiikan esittelyn osalta, hän ei selvästikään yhdy Levinasin käsitykseen, että voin vaatia itseltäni sitä, mitä en voi vaatia toiselta. Toiselta en voi vaatia mitään, mutta olen häneen nähden 'äärettömän vastuullinen'. Kilpeläisen keskustelupanos on kuitenkin tervetullut, sillä kuten Hankamäki teoksessaan sanoo, ihmistieteellisesti pätevän keskustelun tulee sallia voimakkaitakin mielipiteitä ja tunteenpurkauksia. Niitäkään dialoginen filosofia ei välttele, koska se pyrkii asettumaan kiinni ihmisten elämään. Hankamäki on onnistunut toteuttamaan teoksensa idean heittää eettinen haaste tieteen ja politiikan rakkikehään (Yliopisto 14/2003).

Syrjäytyneiden ja vähemmistöjen ongelmat ovat meidän kaikkien ongelmia. Vaikka olisimme niin onnekkaita, että emme kokisi itseämme missään elämämme vaiheessa ulkopuoliseksi tai syrjäytyneeksi - mikä lienee vain teoriassa mahdollista - me pedagogeina kohtaamme väistämättä siten kokevia aikuisia ja lapsia. Mekaanisella normi- ja sääntöetiikalla emme voi heitä auttaa. Auttaisiko kohtaamisetiikka ja kriittinen, dialoginen filosofia, joka pakottaa meidät kanavoimaan uudeksi ajatellut merkitykset toiminnaksi? Kannattaa ainakin kokeilla. Siitä huolimatta, että matkanteko saattaa ajoittain olla melko rajua. Kriittisyydestään ja rajuudestaan huolimatta - tai ehkä juuri niiden takia - Hankamäen kirjaa voi hyvin suositella kasvatustieteiden kurssivaatimuksiin.

Maija Lehtovaara 